\title{
Pemberdayaan Lansia di Bidang Ekonomi (Dusun Jonggrangan)
}

\author{
Danang Wahyu Muhammad \\ Prodi Ilmu Hukum, Universitas Muhammadiyah Yogyakarta \\ Jl. Brawijaya, Tamantirto, Kasihan, Bantul, Yogyakarta, 55183 \\ Email: danangwahyu@umy.ac.id \\ DOI: $10.18196 / p p m .32 .228$
}

\begin{abstract}
Abstrak
Dengan meningkatnya Usia Harapan Hidup Warga Dunia termasuk Indonesia, khususnya yogyakarta menjadi urutan pertama usia harapan hidup menurut BPS Indonesia 2018 jumlah lansia yang masih produktif terus bertambah, diperlukan upaya yang serius agar warga lansia bisa berdaya. Pemberdayaan masyarakat lansia bertujuan agar terjadi perubahan perilaku masyarakat dalam pengembangan ekonomi masyarakat melaui potensi yang dimiliki, Untuk mendorong perekonomian warga Dusun Joggrangan terutama warga senior (lansia) diperlukan adanya terobosan pemberdayaan dibidang ekonomi lansia produktif, melalui peningkatan kualitas produk olahan daun pegagang yang menjadi potensi komoditas potensial daerah dusun jonggrangan.Di Dusun Joggrangan kelompok lansia telah memproduksi Keripik Pegagang sebagai produk olahan, Produk inilah yang kedepannya akan dijadikan produk unggulan Dusun Jonggrangan, harapan besar kedepannya Keripik pegagang menadi produk khas dan unggulan di Jonggrangan banyak macam tetapi memiliki kuliatas unggul yang merata.Pendamping yang diberikan berupa pelatihan pembutan produk yang inovatif dan sesuai standar mutu BPOM , berupa packaging yang lebih menarik, Inovasi produk, pelatihan pemasaran dan survey diperlukan untuk menetukan pangsa pasar produk, dan membuat kelompok lansia di Dusun Jonggrangan.Dengan pendampingan dan penguatan ekonomi lansia dapat menumbuhkan kualitas ekonomi lansia produktif di Dusun Jonggrangan yang sekaligus bisa menjadi contoh lansia produktif untuk daerah lain.
\end{abstract}

Kata Kunci: Pemberdayaan, lansia, Perekonomian, Kripik Pegagang

\section{Pendahuluan}

Daerah Istimewa Yogyakarta menurut BPS tercatat merupakan daerah yang memiliki jumlah penduduk lanjut usia (lansia) tertinggi di Indonesia. Dari total penduduk di kota pelajar tersebut, diperkirakan, lansia mencapai 13,4 persen pada 2015, meningkat 14,7 persen (2020), dan 19,5 persen (2030). Keberhasilan pembangunan kesehatan di Indonesia berdampak terhadap terjadinya penurunan angka kelahiran, angka kesakitan, dan angka kematian serta peningkatan umur harapan hidup (UHH). Salah satu konsekuensinya, sejak tahun 2010 terjadi peningkatan jumlah penduduk lanjut usia (lansia). Tepatnya data Proyeksi Penduduk Indonesia 2010-2035 Badan Pusat Statistik (BPS) menunjukkan peningkatan UHH saat lahir dari 69,8 tahun pada tahun 2010 menjadi 70,9 tahun pada tahun 2017 dan diperkirakan akan meningkat menjadi 72,4 pada tahun 2035 mendatang. Inilah yang disebut transisi menuju struktur penduduk tua (ageing population).

Melihat konteks data tersebut peran perguruan tinggi khususnya perguruan tinggi Yogyakarta harus bisa berkontribusi aktif dalam pemberdayaan lansia sehat . dalam hal ini Kulonprogo menjadi lahan pemberdayaan UMY dalam berpartisipasi pemberdayaan lansia dalam bidang Ekonomi khususnya lansia yang masih produktif dan siap menjadi penggerak roda perekonomian di Desa Jatimulyo Kulonprogo,

Dusun Jonggrangan Desa Jatimulyo merupakan lokasi pemberdayaan KKN PPM, khususnya di bidang indutri olahan makanan kecil dengan potensi sumberdaya alam pegagan yang belum termanfaatkan dengan baik, dimana banyak lansia menjadikan tumbuhan tersebut makanan sehat tapi belum dilah secara baik dan layak pasar, dalam program pemberdayaan itu penulis membuat program untuk lansia agar paham dan bisa dalam memproduksi olahan pegagan yang 
bisa dinikmati banyak orang dan terdistribusi tidak hanya di Desa Jatimulyo tapi bisas tersebar ke jaringan masyarakat lebih luas lagi.

\section{Metode Pelaksanaan}

Secara umum metoda dasar yang digunakan adalah metode Participatory Rural Appraisal (PRA), yang didalamnya melingkupi kegiatan: Pelatihan, Pendampingan, Focus Group Discussion (FGD) dan Workshop. Adanya pandemi COVID-19 mengharuskan setiap kegiatan dilaksanakan dengan protokol COVID-19, atupun kegiatan pendampingan secara online dengan tujuan mengantisipasi penyebaran virus COVID-19. Rincian tahapan pelaksanaan dapat dilihat pada tablel 1 .

Tabel 1. Tahapan Pelaksanaan Program

\begin{tabular}{|c|c|c|}
\hline Tahapan & Kegiatan & Teknologi/Metode \\
\hline Sosialisasi & $\begin{array}{ll}- & \text { Pembentukan Tim } \\
\text { - } & \text { Observasi dan Transfer Informasi } \\
& \text { Program } \\
\text { - } & \text { Penyuluhan }\end{array}$ & $\begin{array}{l}\text { - } \quad \text { Observasi \& FGD } \\
\text { - } \quad \text { Penyuluhan tentang pentingnya pengelolaan } \\
\text { daun Pegagang menjadi olahan kripik } \\
\text { Pegagang untuk meningkatkan taraf ekonomi }\end{array}$ \\
\hline Masuk Komunitas & $\begin{array}{ll}\text { - } & \text { Proses masuk ke komunitas } \\
\text { - } & \text { Membangun hubungan } \\
\text { - } & \text { Toktry Point Issue } \\
& \text { dan penghambat }\end{array}$ & - $\quad$ FGD \\
\hline Open Issue & $\begin{array}{ll}\text { - } & \text { Pengkajian situasi dan kondisi } \\
\text { - } & \text { Menentukan kegiatan teknik }\end{array}$ & $\begin{array}{ll}- & \text { Observasi } \\
- & \text { Wawancara } \\
\text { - } & \text { FGD } \\
\text { - } & \text { Narasumber }\end{array}$ \\
\hline $\begin{array}{l}\text { Pemberdayaan } \\
\text { Masyarakat (teknis } \\
\text { transfer teknologi) }\end{array}$ & $\begin{array}{ll} & \text { Pelatihan } \\
\text { - } & \text { Pendampingan } \\
\text { - } & \text { Workshop }\end{array}$ & $\begin{array}{ll}\text { - } & \text { FGD } \\
\text { - } & \text { Pelatihan Motivasi } \\
& \text { Pelatihan teknis keterampilan pengelolaan } \\
& \text { daun pegagang menjadi kripik pegagang yang } \\
& \text { enak, bergizi dan kemasan yang higinis }\end{array}$ \\
\hline $\begin{array}{l}\text { Pengkaderan, } \\
\text { Membangun Dukungan, } \\
\text { dan Penguatan } \\
\text { Kelembagaan }\end{array}$ & $\begin{array}{ll}\text { - } & \text { Pengkaderan dan pelibatan peran } \\
\text { - } & \text { Penguatan kelembagaan }\end{array}$ & $\begin{array}{ll}\text { - } & \text { FGD } \\
\text { - Penguatan kelembagaan Ibu - ibu kelompok } \\
\text { Lansia untuk memproduksi kripik Pegagang } \\
\text { sebagai olahan ciri khas di Dusun } \\
\text { Jonggrangan }\end{array}$ \\
\hline Phasing Out & - $\quad$ Monitoring dan Evaluasi & $\begin{array}{ll}- & \text { FGD Aturan Bersama } \\
\text { - } & \text { FGD Tim Monitoring }\end{array}$ \\
\hline
\end{tabular}

\section{Hasil dan Pembahasan}

\section{A. Profil Kelompok Sasaran}

Pedukuhan Jonggrangan terletak di Desa Jatimulyo Kecamatan Girimulyo Kabupaten Kulo Progo Daerah Istimewa Yogyakarta, Desa ini terletak dibarisan perbukitan menoreh wilayah utara Knbu paten Kulon Progo, Daerah Jstimewa Yogyakarta, yang berbatasan dengan wilayah Kabupaten Purworejo, Jawa Tengah, dengan ketinggian sekitar 700 meter di atas permukaan laut atau lebih tepatnya diatara pegunungan menorah kulonprogo yang termasyhur subur dan cocok unukt pertanian dataran tinggi. Dusun jonggrangan terdapat $8 \mathrm{rt}$ dan $2 \mathrm{RW}$, kegiatan kemasayrakatan dusun jonggrangan cukup aktif dari segi dasawisma , Lansia, Karang Taruna

Dalam, hal ini Lansia termasuk menempati jumlah tertinggi dari kategori usia setelah paruh baya yang memang notabene masih usia produktif, pemuda/i dusun jonggrangan mayoritas merantau sehingga gap usia di dusun jonggrangan terlampau jauh antara muda dan lansia. 


\section{B. Pelaksanaan Pemberdayaan}

1. Observasi, Silaturahmi dan brainstorming dengan tokoh masyarakat, struktur Desa dan Dusun serta tokoh Lansia setempat. Kegitatan ini disampaikan dalam rangka memaparkan rencana pengabdian dan pendampingan di dusun jonggrangan dalam kurun waktu 3 bulan kedepan terhitung bulan Februari hingga April, dalam kaitanya observasi tersbut melakukan assessment produktivitas lansia jonggrangan.

2. Kunjungan Khusus Ke Kelompok Lansia Dusun Jonggrangan melihat langsung kegiatan lansia sehari hari guna memetakan kesiapan dan kecakapan lansia Jonggrangan.

3. Penyuluhan dan sosialisasi manfaat tanaman pegagan yang bayak dijumpai di dusun jonggrangan tapi belum temrmanfaatkan secara maksimal yang kemudian menjadi komoditas pokok kelompok lansia jonggrangan dalam penyokong ekonomi dasar.

4. Pelatihan membuat dan mengolah keripik pegagan menjadi makanan layak konsumsi dan sesuai standar industry rumahan yang kemudian siap menjadi standar produksi dinkes PIRT (pangan industri rumah tangga),kegiatan tersebut dimulai dengan mengolah pegagan dari bahan mentah kemudian dimasak sesuai standar kebersihan dinskes.

5. Pelatihan dan workshop mengemas hasil olahan pegagan siap konsumsi dan layak pasar, kegiatanya memberi wawasan atau template pengemasan yang baik dan menarik perhatian calon pembeli ,memberi wawasan pengemasan yang kuat dan tahan lama.

6. Pendampingan Uji coba rasa dilakukan lewat mengundang warga jonggrangan untuk menrima masukan terkait produksi olahan pegagan buatan lansia jonggrangan

7. Pendampingan Tes pasar dilakukan di alun-alun kulonprogo guna melihat respon pasar untuk makanan khas jonggrangan .

8. Hibah alat bantu operasional untuk mengolah pegagan diwakilkan kepada kepala dukuh jonggrangan berupa satu set alat masak, alat kemas, dan alat timbang seharga Rp 3.000.000 guna membantu kelompok lansia jonggrangan dalam memudahkan pridukiftas ny dalam mengolah pegagan.

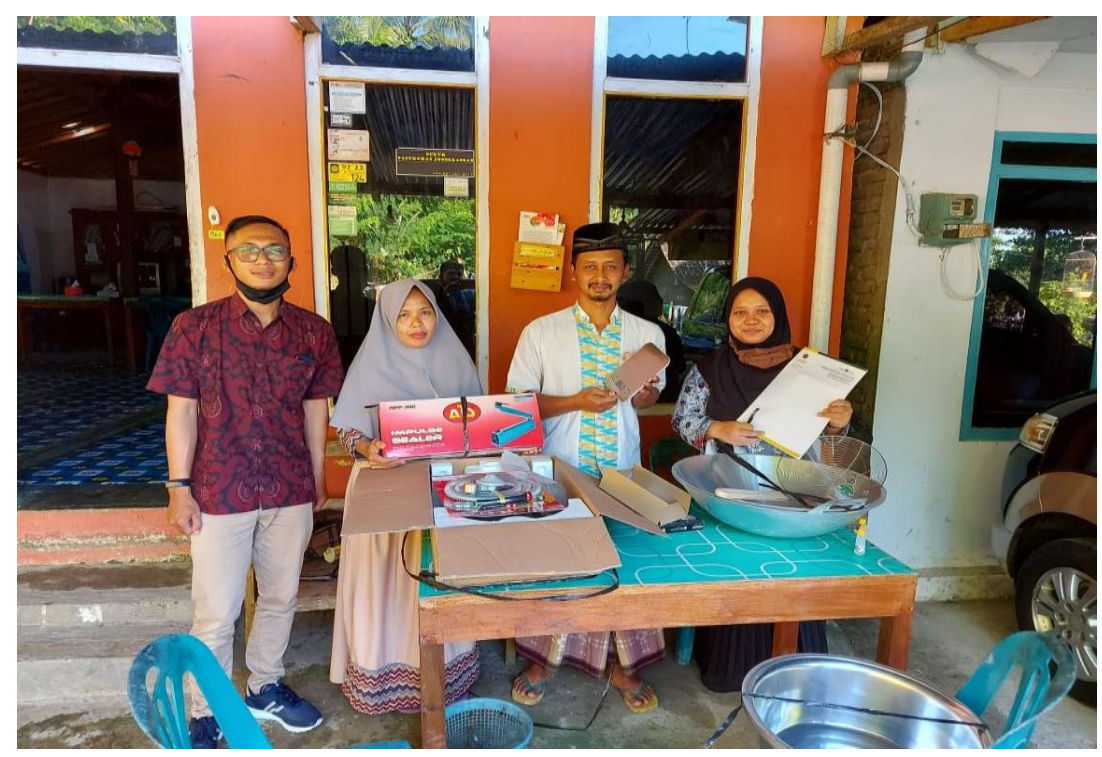

Gambar 1.Penyerahan Hibah Alat Bantu Operasional 


\section{Simpulan}

Program pengabdian dan pendampingan lansia dalam menghidupkan produktiftas ekonomi setempat, di dusun Jonggrangan, Desa Jatimulyo Kecamatan Giripurwo Kabupaten Kulonprogo yang diadakan selama 3 bulan lebih. Hasil pelaksanaan dalam program tersebut adalah sebagai berikut:

1. Sosialisasi dan brainstorming awal yang diikuti oleh tokoh masyarakat ,struktur Desa dan tokoh lansia terkait focus pengabdian dan pendampingan selama kurang lebioh 3 bulan kedepan mendapat apresiasi yang positif dan dukungan penuh dalam perjalanan kegiatan pengabdian masayarkat.

2. Pelatihan dan penyuluhan terkait mengolah dan mengemas pegagan yang layak konsumsi dan layak jual. Mendapat hasil yang cukup memuaskan 20 dari 30 lansia undangan yang hadir merasa bisa dan mempraktekan sendiri dirumahnya masing-masing.

3. Uji coba rasa dan uji coba pasar mendapat respond dan feedback positif dari masyarkat terutama terkait rasa dan pengemasan yang menarik perhatian, dari hasil ujicoba tersbeut para lansia merasa termotivasi untuk meningkatakan produktiftasny dalam mengolah pegagan.

4. Penyerahan hibah operasional telah mampu meningkatkan komitmen kelompok lansia dusun jonggrangan menjadi lebih siap dan layak terjun ke produksi pasar industry rumahan.

\section{Ucapan Terima Kasih}

Dengan ini kami ingin menyampaikan ucapan terima kasih kepada pihak - pihak yang telah memberikan dukungan dan bantuannya atas berjalannya program ini, baik berupa materi dan moril di antaranya, Bapak Mardiyanta selaku Kepala Desa Jatimulyo, Bapak Sutarman selaku Kepala Dusun Jonggarangan, Seluruh warga Dusun Jonggrangan khususnya kelompok lansia dan Lembaga Penelitian, Publikasi dan Pengabdian Masyarakat, Universitas Muhammadiyah Yogyakarta.

\section{Daftar Pustaka}

Chamber, Robert. (1994). "The Origins and Practice of Participatory Rulal dalam World Development". 22 (7): 953 - 969.

Hudayana, Bambang. (2017). Pemberdayaan Masyarakat, Bunga Rampai Antropologi Terapan. Yogyakarta: Pustaka Pelajar.

Muller, Jocelyn G. Dkk. (2010). "Evaluating Rapif Participatory Rural Apprasial asn an Assesment of Ethnoecoligical Knowledge and Local Biodiversity Patterns" dalam Conservation Biology, 24 (1) : 140-150.

Sinha, K. Prabhakar. (1997). "In Defence of Participatory Rural Apprasial” dalam Ecconomies and Political Weekly, 32 (13): 672.

Soetoomo,2012.Keswadayaan Masyarakat Manivestasi Kapasitas Masyarakat untuk Berkembang Secara Mandiri. Yogyakarta : Pustaka Pelajar.

Suparjan \& Hempri Suyatno. (2003). Pengembangan Masyarakat dari pembangunan Sampai Pemberdayaan. Yogyakarta: Aditya Media.

Widodo. A.S. (2019). Teknik Fasilitasi Pemberdayaan Masyarakat.UMY Press, Lembaga Penelitian, Publikasi dan Pengabdian Masyarakat, Universitas Muhammadiyah Yogyakarta. 